\title{
Phenolics from Barleria cristata var. Alba as carcinogenesis blockers against menadione cytotoxicity through induction and protection of quinone reductase
}

\author{
Ali M. El-Halawany ${ }^{1,2}$, Hossam M. Abdallah ${ }^{1,2^{*}}$, Ahmed R. Hamed ${ }^{3}$, Hany Ezzat Khalii ${ }^{4,5}$ \\ and Ameen M. Almohammadi ${ }^{6}$
}

\begin{abstract}
Background: There are increasing interests in natural compounds for cancer chemoprevention. Blocking agents represent an important class of chemopreventive compounds. They prevent carcinogens from undergoing metabolic activation and thereby suppressing their interaction with cellular macromolecular targets.

Methods: The effect of phenolic compounds isolated from Barleria cristata var. alba as chemopreventive agent was evaluated. The ethyl acetate fraction of $B$. cristata was subjected to different chromatographic techniques for isolation of its major phenolic compounds. The isolated compounds were evaluated for their potential to induce the cancer chemopreventive enzyme marker $\mathrm{NAD}(\mathrm{P}) \mathrm{H}$ quinonereductase 1 (NQO1) in murine Hepa-1c1c7 cell model.

Results: The ethyl acetate fraction of B. cristata var. alba yielded five known compounds identified as verbascoside (1), isoverbascoside (2), dimethoxyverbascoside (3), p-hydroxy benzoic acid (4), and apigenin-7-O-glucoside (5). Among the tested compounds, isoverbascoside (2) was shown to potently induce the activity of the enzyme in a dose-dependent manner. As a functional assay for detoxification, compound 2 was the strongest to protect Hepa1c1c7 against the toxicity of menadione, a quinone substrate for NQO1.
\end{abstract}

Conclusion: This effect seemed to be attributed to the compound's potential to induce both the catalytic activity and protein expression of NQO1 as revealed by enzyme assay and Western blotting, respectively.

Keywords: Chemoprevention, Quinonereductase 1, Menadione, Phenolic compounds

\section{Background}

Cancer is a condition in which a cell divides and grows in an uncontrolled manner forming a neoplastic tumor which may spread to other tissues and becomes malignant. Cancer incidence is neither rare anywhere in the world, nor restricted to rich countries. However, deaths from cancer in developing countries are higher than in developed countries [1]. Therefore it is becoming highly recognized that the strategies for cancer prevention are

\footnotetext{
* Correspondence: hmafifi2013@gmail.com

1 Department of Natural Products, Faculty of Pharmacy, King Abdulaziz

University, Jeddah 21589, Saudi Arabia

${ }^{2}$ Department of Pharmacognosy, Faculty of Pharmacy, Cairo University, Cairo

11562, Egypt

Full list of author information is available at the end of the article
}

forming the logic and cost effective approach to control this global problem of cancer mortalities as alternative to the high costs of the chemotherapy or radiotherapeutic programs and this should reflect positively on the local and global economies. There are increasing interests in natural compounds for chemoprevention against cancer. These great interests are mainly due to a high number of population studies that showed reduced cancer risk in people consuming dietary phytochemicals compared to people who consume less dietary phytochemicals [2]. Based on the classified stages of carcinogenesis process, the term 'cancer chemoprevention' has been defined as the use of relatively non-toxic chemical agent (natural or synthetic) to inhibit, arrest or reverse the carcinogenesis

(c) The Author(s). 2018 Open Access This article is distributed under the terms of the Creative Commons Attribution 4.0 International License (http://creativecommons.org/licenses/by/4.0/), which permits unrestricted use, distribution, and reproduction in any medium, provided you give appropriate credit to the original author(s) and the source, provide a link to the Creative Commons license, and indicate if changes were made. The Creative Commons Public Domain Dedication waiver (http://creativecommons.org/publicdomain/zero/1.0/) applies to the data made available in this article, unless otherwise stated. 
at early stages [3, 4]. Blocking agents is one important class of compounds in chemoprevention. They prevent carcinogens from undergoing metabolic activation and thereby suppressing their interaction with cellular macromolecular targets such as DNA, RNA and proteins. Blocking agents elicit chemopreventive actions through the induction of a set of phase II detoxifying and antioxidant enzymes such as the chemopreventive marker $\mathrm{NAD}(\mathrm{P}) \mathrm{H}$ quinonereductase 1 (NQO1 or QR1), glutathione-stransferase (GST), UDP-glucuronosyltransferase (UGT), $\gamma$-glutamate cysteine ligase $(\gamma-G C L)$, glutathione reductase (GR), catalase and Mn superoxide dismutase which act in the detoxification and elimination of harmful reactive intermediates and oxidative stress [5]. There have been accumulating evidences for the promising value of natural products in chemoprevention against cancer. The reason for this is largely due to their low toxicity and high diversity of their chemical structures [6].

Genus Barleria is belonging to family Acanthaceae. Ten species from this genus are growing in Saudi flora. Plants belonging to this genus are widely used as an ethnomedicines for variety of illnesses [7, 8]. Barleria cristata L. as an example of this genus is an ornamental plant with two varieties named on the basis of their flower color including var. alba and var. purpurea for the white and purple flowers, respectively. B. cristata var. purpurea is also known as Philippine Violet or Blue Bell Barleria. Leaves and stems of the plant are used as anti-inflammatory, anemia treatment, antiplasmodial, anti-oxidant and analgesic for toothache. The plant was reported to contain alkaloids, flavonoids, iridoids and to be rich in phenolic contents [8].

The phenolic content of the plant encouraged its use as a chemopreventive and cytoprotective agent. In addition, there is no published chemical or biological data on the other variety (alba) of the plant, which encouraged us to investigate its possible chemopreventive effect, based on expected similarity in active constituents' classes to that of the variety purpurea. Therefore, in continuation to our interest in isolating bioactive chemopreventive agent from plants [5] and based on the chemopreventive activity of phenolics [9], which represent a major constituent in, B.cristata var. alba, the current study was performed.

\section{Methods}

\section{General experimental procedures}

UV spectra were recorded in $\mathrm{MeOH}$ using a UV IKON940 spectrophotometer.1D and 2D NMR spectra (chemical shifts in ppm and coupling constants in $\mathrm{Hz}$ ) were recorded on a Bruker DRX-600 MHz Ultrashield spectrometer (Bruker BioSpin, Billerica, MA, USA) using DMSOd6 as solvent, with TMS as the internal reference. Column chromatographic separations were performed on silica gel 60 (70-230 mesh, Merck, Darmstadt, Germany), Silica gel $100 \mathrm{C}_{18}$-Reversed phase $(0.04-0.063 \mathrm{~mm}$, Merck, Darmstadt, Germany) and Sephadex LH20(Pharmacia Fine Chemicals Inc., Uppsala, Sweden). TLC analysis was performed on pre-coated TLC plates with silica gel $60 \mathrm{~F}_{254}$ (Merck, Darmstadt, Germany). Purification of the isolated compounds was performed on a preparative HPLC Agilent1200 equipped with a multi-wavelength detector and ZorbaxSB-C18 column $(9.4 \times 250 \mathrm{~mm})$.

\section{Plant material}

Aerial parts of B. cristata L. var. alba were collected from El-Orman Public Garden, Giza, Egypt during April and June 2010. Authentication of plant material was established by Agricultural Engineer Traiz Labib, taxonomy specialist in El-Orman public garden, Giza, Egypt. Voucher specimen (Reg. No. BS1110) is kept in the Herbarium of the Department of Natural Products and Alternative Medicine, Faculty of Pharmacy, King Abdulaziz University, KSA.

\section{Materials for the biology}

All chemicals and reagents for cell culture and bioassays were purchased from Lonza (Verviers, Belgium) or Sigma-Aldrich (Steinheim, Germany). Plastic ware for cell culture and assays were prom Griener Bio One (Frickenhausen, Germany). Murine hepatoma cells (Hepa1c1c7, ATCC, USA).

\section{Extraction and isolation of main active constituents}

The air dried powdered aerial parts $(3 \mathrm{Kg}$ ) were exhaustively extracted at room temperature (14 days) using $25 \mathrm{~L}$ $70 \%$ methyl alcohol, applying cold maceration method to avoid damage of active principals. The solvent mixtures were distilled off under reduced pressure using rotary evaporator and then freeze-dried to yield the total dry extract $(210 \mathrm{~g})$, which was stored in deep freezer for further analysis. The total extract was suspended in water $(500 \mathrm{~mL})$ and fractionated with chloroform $(3 \times$ $1 \mathrm{~L})$ followed by EtOAc $(3 \times 1 \mathrm{~L})$ and finally $n$-butanol saturated with water. The EtOAc fraction $(10 \mathrm{~g})$ was fractionated using RP-18 VLC $(5 \times 20 \mathrm{~cm})$ using $\mathrm{MeOH}$ : $\mathrm{H}_{2} \mathrm{O}(0-70 \% \mathrm{v} / \mathrm{v}, 5 \%$ increment $)$ and four major fractions were collected. Fraction $1(2.3 \mathrm{~g})$ was placed on silica gel column $(2 \times 50 \mathrm{~cm})$ using $\mathrm{CHCl}_{3}: \mathrm{MeOH}$ (9.5:0 $5 \mathrm{v} / \mathrm{v})$ as mobile phase. Subfraction $1-5$ was further purified using Sephadex LH-20 $(2 \times 50 \mathrm{~cm})$ using $\mathrm{MeOH}$ as an eluent to give $50 \mathrm{mg}$ of $\mathbf{1}$. Fraction 2 was rechromatographed on silica gel column $(2 \times 50 \mathrm{~cm})$ using Hexane:EtOAc (1:1) to give $20 \mathrm{mg}$ of compound 2.Subfraction3 was purified on RP-18 HPLC using the following mobile phase system acetonitrile: water $(2: 8)$ to yield 
two pure compounds $3(3 \mathrm{mg})$ and 4 (5 mg). Fraction 4 was purified on RP-18 HPLC using the following mobile phase system acetonitrile: water (3:7) to yield compound 5 (2 mg).

\section{Hepa-1c1c7 cell culture}

Murine hepatoma cell line Hepa-1c1c7 was maintained as monolayer culture in $\alpha$-modified Minimum Essential Medium Eagle ( $\alpha$-MEME) supplemented with $10 \%(v / v)$ heat-and charcoal-inactivated fetal bovine serum, $2 \mathrm{mM}$ L-glutamine, $100 \mathrm{U} / \mathrm{ml}$ penicillin, $100 \mu \mathrm{g} / \mathrm{ml}$ streptomycin sulphate in humidified incubator (Sartorius CMAT, Germany, $5 \% \mathrm{CO}_{2} / 95 \%$ air). At about $80 \%$ confluence, cells were routinely sub-cultured with Trypsin EDTA solution.

\section{Assessment of the induction of NQO1 in Hepa-1c1c7 cells} The induction of NQO1 in Hepa-1C1C7 cells was assessed. Briefly, cells $\left(1.5 \times 10^{5}\right.$ cells $\left./ \mathrm{ml}\right)$ were seeded onto 6-well plates and left overnight to adhere and form semi-confluent monolayers. Monolayers were treated with either vehicle (final concentration $0.5 \% v / \mathrm{v}$ DMSO) or test compounds for additional $48 \mathrm{~h}$. Media were then aspirated and monolayers were washed with ice-cold Dulbecco's PBS ( $1 \mathrm{ml} /$ well). Cells were then scrapped in ice-cold lysis buffer ( $25 \mathrm{mMTris-Cl}, \mathrm{pH}$ 7.4, $250 \mathrm{mM}$ sucrose and $5 \mu \mathrm{M}$ FAD) and transferred to microcentrifuge tubes. Cell suspensions were then sonicated on ice for 5 s (20\% amplitude). Sonicates were then centrifuged $(15,000 \times \mathrm{g}$ for $10 \mathrm{~min})$ and the supernatant (cytosolic fraction) was aliquoted and stored at $-80{ }^{\circ} \mathrm{C}$ until assayed.

\section{NQO1 assay}

The dicoumarol-sensitive NQO1 activity was measured in cell lysate according to [10] as optimized in our laboratory for spectrophotometer measurement in $500 \mu \mathrm{l}$ cuvettes. Briefly, the reaction mixture contained in a final volume of $500 \mu \mathrm{l}: 25 \mathrm{mM}$ Tris buffer ( $\mathrm{pH} 7.4$ ), 0 . $7 \mathrm{mg} / \mathrm{ml}$ bovine serum albumin, $5 \mu \mathrm{M}$ FAD, $0.2 \mathrm{mM} \beta$ $\mathrm{NADH}$ as electron donor, $20 \mu \mathrm{M}$ 2,6-dichlorophenolindophenol (DCPIP) as electron acceptor in the absence (total reductase activity) or the presence of $20 \mu \mathrm{M}$ dicoumarol (inhibited non-NQO-1 activity). The reaction was started by the addition of $10 \mu \mathrm{l}$ of supernatant of cell lysates to $490 \mu \mathrm{l}$ of the reaction mixture in disposable cuvettes. The kinetic determination of enzyme activity was carried out using UV-visible spectrophotometer monitoring the decrease in absorbance of DCPIP at $600 \mathrm{~nm}$ for $1 \mathrm{~min}$. The instrument software was used to calculate the average reaction rate per minute $(\Delta \mathrm{A} /$ minute). Total proteins were determined using Bradford assay [11]. The enzyme activity was normalised to $1 \mathrm{mg}$ of total proteins and expressed as $\Delta \mathrm{A} /$ minute/mg protein.

\section{Effect of compounds on menadione-induced cytotoxicity in Hepa-1c1c7 cells}

First, The cytotoxic effect of menadione (MD), a quinone substrate for NQO1, on Hepa-1c1c7 cells was determined using a modified sulforhodamin B assay for cellular protein content which is essentially based on method mentioned by [12]. Briefly, Hepa-1c1c7 cells $(100,000 \mathrm{cells} / \mathrm{ml})$ were seeded onto 96 -well plates and incubated to adhere overnight at $5 \% \mathrm{CO}_{2} / 95 \%$ air incubator. At the next day, cells were treated with either vehicle $(0.1 \%$ DMSO) or increasing concentrations of menadione $(1.5-100 \mu \mathrm{M})$ and incubated for further $24 \mathrm{~h}$. Culture medium was then aspirated and monolayers were fixed with $10 \% \mathrm{TCA}$ for $1 \mathrm{~h}$ at $4{ }^{\circ} \mathrm{C}$ after which all wells were washed with deionized water ( 4 washes). Air-dried plates were then stained with $0.4 \%$ SRB in $1 \%$ acetic acid for $30 \mathrm{~min}$ at room temperature. Excess dye was removed with washing with $1 \%$ acetic acid (4 washes). Bound SRB in air-dried plates were then quantified by solubilisation in $10 \mathrm{mM}$ unbuffered Tris base. The absorbance (OD) was read at $540 \mathrm{~nm}$ on a microplate reader (FLUOstar Optima, BMG LABTECH GmbH, Ortenberg, Germany). Percentage viability to vehicle control $(100 \%)$ was calculated from the mean values of the OD of test concentrations. Dose response curves were plotted on Graphpad Prism V6.0 and analysed using non-linear regression to calculate the concentration of MD causing $50 \%$ cytotoxicity $\left(\mathrm{IC}_{50}\right)$.

To test the potential of compounds 1, 2, 4 and 5 to protect Hepa-1c1c7 cells against MD cytotoxicity, cells were pre-treated with either DMSO or $3.125 \mu \mathrm{M}$ from compounds for $24 \mathrm{~h}$ before being intoxicated with $20 \mu \mathrm{M}$ of menadione (MD) for a further $24 \mathrm{~h}$. The Plate was then air-dried and processed for SRB cytotoxicity assay as mentioned above.

\section{NQO1 western blotting}

Cells were cultured and treated as mentioned above. NQO1 protein expression was assessed in cell sonicates by Western blotting. Samples, including vehicle control, positive control (sulforaphane at $5 \mu \mathrm{M}$ ) and compound 2-treated lysates $(15 \mu \mathrm{g}$ total proteins/lane) were resolved by electrophoresis on $10 \%$ acrylamide/bis acrylamide gel (200 Volts for $1 \mathrm{~h}$ ). Resolved proteins were then transferred to nitrocellulose membrane at $100 \mathrm{~V}$ for 90 min. Membranes were blocked in 5\% non-fat milk in Tris-buffered saline with $0.1 \%$ Tween 20 (TBST) for $1 \mathrm{~h}$ at $25{ }^{\circ} \mathrm{C}$ and then probed overnight $\left(4{ }^{\circ} \mathrm{C}\right)$ with primary antibodies against NQO1 and $\beta$-actin (abcam, UK). After three washes in TBST (10 min each), membranes were probed with appropriate secondary antibodies for $1 \mathrm{~h}$ 
at $25{ }^{\circ} \mathrm{C}$, washed three times in TBST and then developed using enzyme chemiluminescence (ECL). Protein bands were visualized on developed membranes using $\mathrm{x}$-ray film. Protein band intensities were determined and normalized to $\beta$-actin using Image Studio Lite software v $5.2\left(\mathrm{Li}^{-\mathrm{COR}^{\circ}}\right.$ Biosciences, USA).

\section{Results}

The ethyl acetate fraction of B. cristata var. alba yielded five known compounds. The isolated compounds (Fig. 1) were identified based on their NMR data (Additional file 1: Figures S1-10) and by comparison with the reported data as; verbascoside (1) [13], isoverbascoside (2) [13], dimethoxyverbascoside (3), p-hydroxybenzoic acid (4) [14] and apigenin-7-O-glucoside (5) [15].

\section{Induction of NQO1 activity by B.Cristata var. alba phenolic constituents}

In the present study, we evaluated compounds $(1,2,4$ \& 5) isolated from $B$. cristata for their potential to induce the cancer chemopreventive marker enzyme NQO1 in murine Hepa-1c1c7 cells. A shown in Fig. 2, tested compounds caused differential potencies as inducers for the activity of NQO1 following a $48 \mathrm{~h}$ treatment period. The most active compound was shown to be compound 2 (isoverbascoside) causing 8.8-fold induction of NQO1

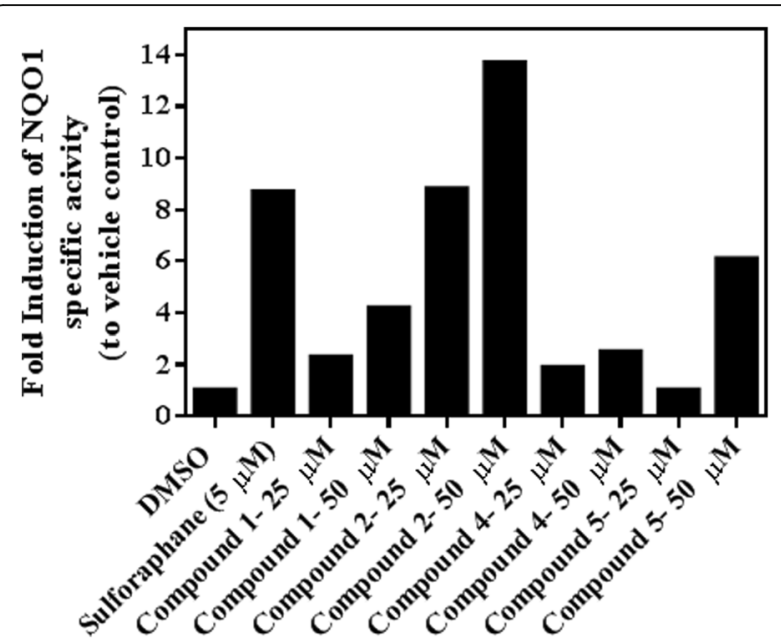

Fig. 2 Fold induction of $\mathrm{NQO} 1$ activity by isolated compounds $\mathbf{1 , 2 , 4}$ and $\mathbf{5}$ Hepa-1c1c7 were treated with either vehicle (DMSO) or indicated concentrations of the compounds for $48 \mathrm{~h}$ and then cell lysates were assayed for NQO1 activity as described in the Materials and Methods section

activity at $25 \mu \mathrm{M}$ over vehicle control activity level. Higher inducer potency (13.9-fold over control) was recorded with $50 \mu \mathrm{M}$ of compound 2. Lower inducer activities were shown by compounds $\mathbf{1}, \mathbf{4}$ and $\mathbf{5}$ as displayed in Fig. 2.

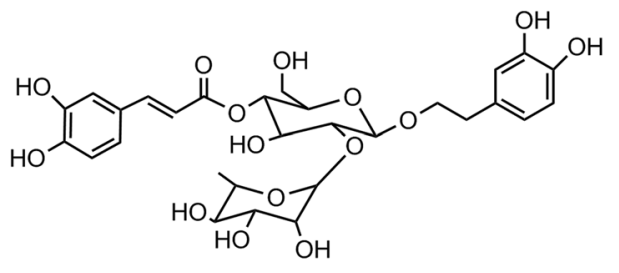

1

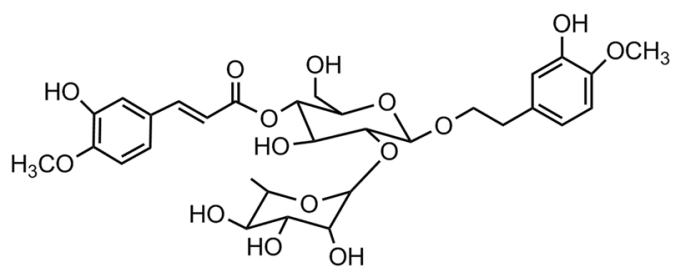

3

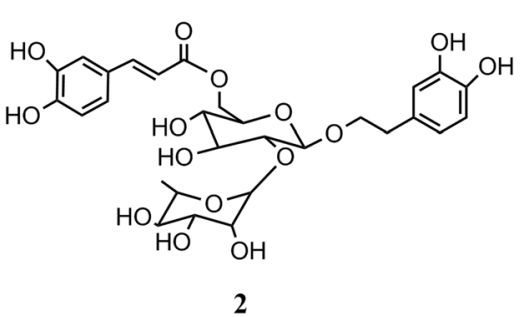<smiles>O=C(O)c1ccc(O)cc1</smiles>

4<smiles>O=c1cc(-c2ccc(O)cc2)oc2cc(OC3OCC(O)C(O)C(O)C3O)cc(O)c12</smiles> 


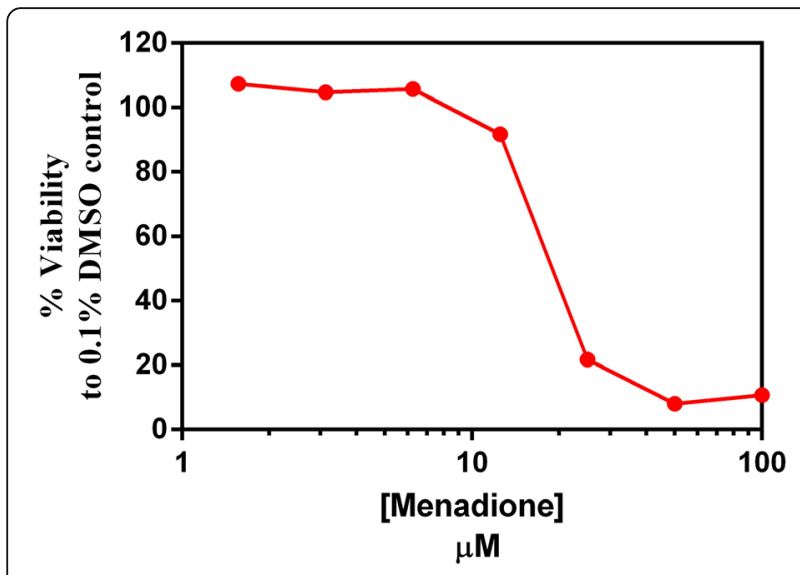

Fig. 3 Concentration-response curve of the toxicity of Menadione on Hepa-1c1c7 cells. Cells were cultured and treated with MD $(1.5-100 \mu \mathrm{M})$ for $24 \mathrm{~h}$ and then assayed using SRB cytotoxicity assay as described in the Experimental section, each data point represents means of Octuplet well treatments

Effect of compounds from B. cristata on menadioneinduced toxicity (functional assay of NQO1)

Among the tested compounds (Fig. 3), compound 2 (isoverbascoside) was the most active one to protect Hepa1c1c7 cells against MD cytotoxicity. This is matched with the potency of this compound as NQO1 inducer (Fig. 2). The induction of NQO1 by isoverbascoside helped to detoxify MD through 2-electron reduction to the hydroquinone form menadiol. Menadiol is easily excreted and this prevents the phase I single electron reduction of $\mathrm{MD}$ to the toxic semiquinone. Lower protection was produced by the other compounds which

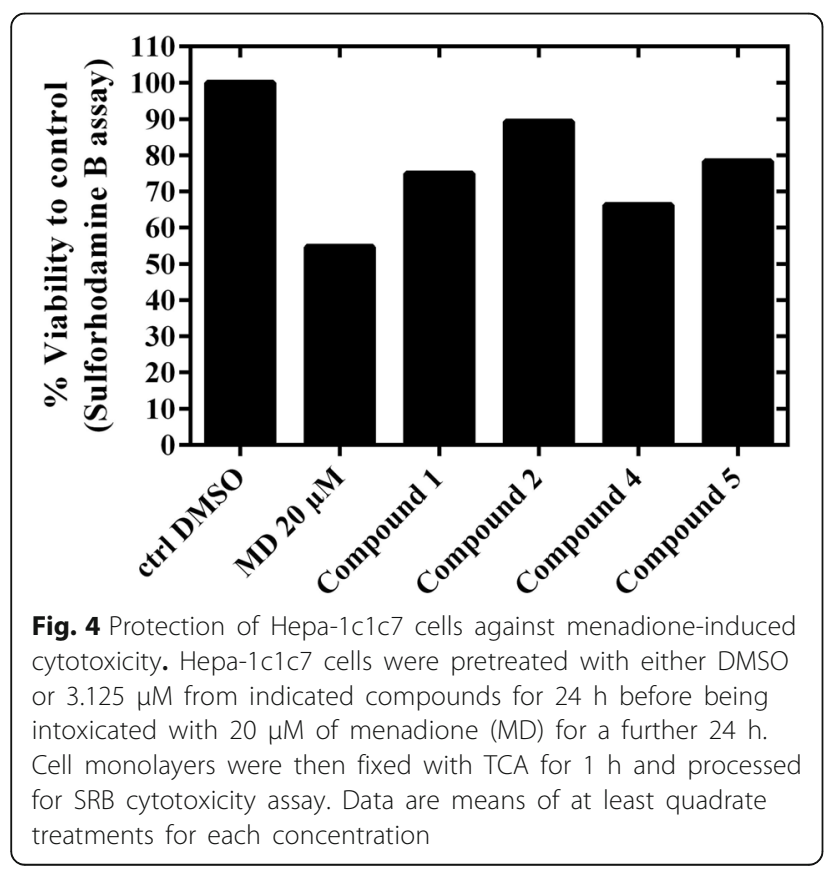

can be ordered from high to low activity as Compound $5>$ Compound $1>$ Compound 4 as displayed in Fig. 4.

Compound 2 was also shown to cause a concentrationdependent upregulation of the protein expression level of NQO1 using Western blotting analysis as displayed in Fig. 5a and b.

Taken together, the present study shed some light on the mechanism-based potential of the phenolic constituents of the ornamental plant B. cristata var. alba as chemopreventive agents. As shown, this activity is through the induction of the cytoprotective enzyme NQO1 at the activity and protein expression levels.

\section{Discussion}

Many experimental evidences exist to support the protective roles of NQO1 in the prevention against the toxicity and neoplastic effects of quinones, quinoneimenes and azo dyes in vitro as well as in experimental animals. For example, Wu et al., [16] investigated the protective role of indole-3-carbinol (I3C), a known cruciferous NQO1 inducer, to reduce the incidence of prostate cancer in mice model of transgenic adenocarcinoma of mouse prostate (TRAMP mice). Feeding TRAMP mice with $1 \%$ I3C diet has significantly abolished the number of palable tumors, compared with the untreated TRAMP group. This effect was found to occur via the induction

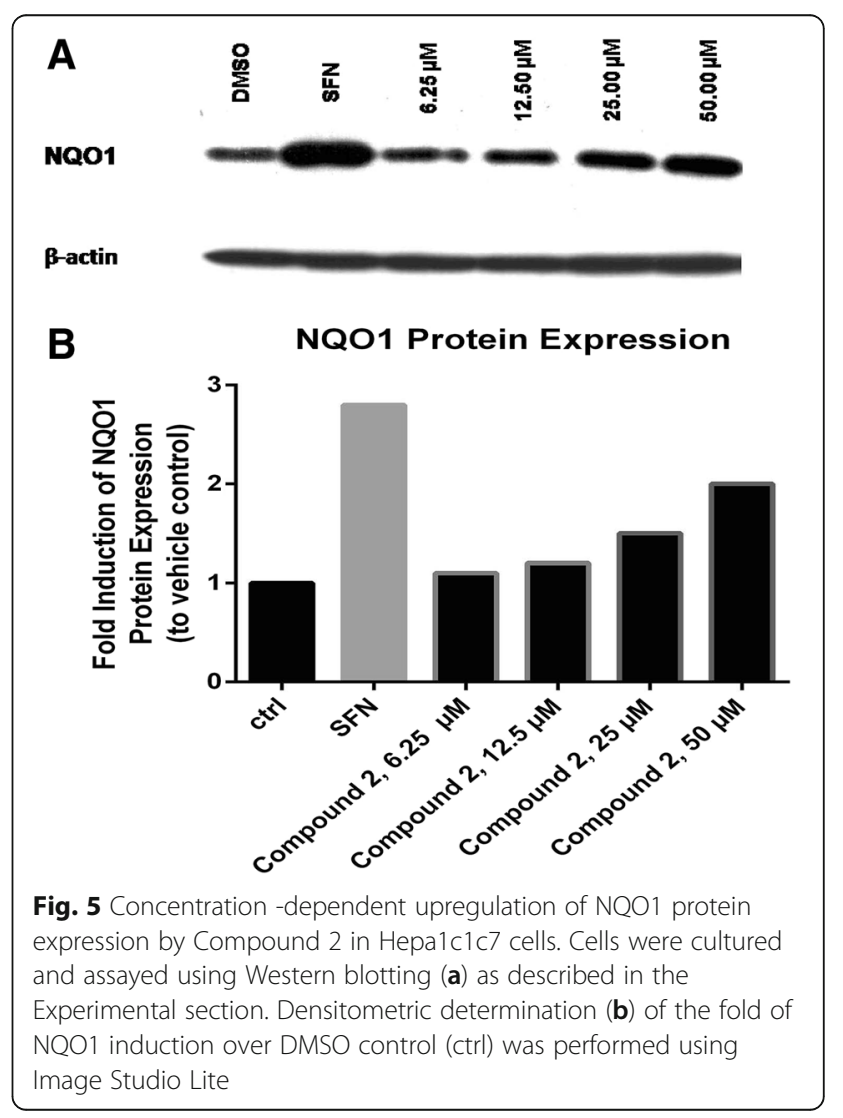


of the Nrf2-target gene NQO1 expression. The induction of Nrf2-target genes NQO1 and Glutathione S Transferase (GST) by ursolic acid inhibited the development of lung cancer in nude mice injected with the lung cancer cells A549 [17]. Moreover, inducers of NQO1 in vitro in the Hepa-1c1c7 model were also able to suppress the carcinogenic effects of diverse cancer promoting agents related to different types of cancers, with sulforaphane being the prototype NQO1 inducer [18, 19]. Phenolic phytochemicals were found to be potent inducers of NQO1 by many investigators. For example, (+)-tephropurpurin, a chalcone isolated from Tephrosia purpurea induced NQO1 activity in the murine hepatoma hepa-1c1c7 model [20]. Protection against azoxymethane-induced intestinal adenocarcinoma was accomplished in F344 rats administered with the flavonoid morin via significant increase in the activity of GST and NQO1 enzymes over those of untreated control [21]. Morin was also shown to protect against 4nitroquinone 1-oxide-induced tongue carcinogenesis in F344 rat through induction of GST and NQO1 enzymatic activities [22].

In present study; to further elucidate the potency of tested compounds as inducers of the cancer chemopreventive marker NQO1 at the functional level, we used an assay system at which the NQO1 substrate menadione (MD), a toxic quinone which is known to cause redox cycling and oxidative damage through 1-electron reduction catalyzed by NADH Cytochrome $\mathrm{P} 450$ reductase and this results in the formation of unstable toxic semiquinone [23]. NQO1 is known to detoxify quinones through direct 2-electron-reduction into the more water soluble, more stable, easily conjugated hydroquinone and therefore minimizing the formation of the toxic semiquinone metabolite of $\mathrm{MD}[13,24]$.

Treatment of Hepa-1c1c7 cells with $20 \mu \mathrm{M}$ MD alone caused a dramatic loss of cell viability near to $50 \%$ compared to DMSO control (calculated MD $\mathrm{IC}_{50}$ from dose response curve $=19.7 \mu \mathrm{M}$, Fig. 3). Pretreatment of Hepa-1c1c7 cells with $3.125 \mu \mathrm{M}$ from tested compounds inhibited the cytotoxic effect caused by MD treatment, displaying higher cell viability \% of cells compared to the $20 \mu \mathrm{M}$ MD only treated cells. Therefore, the protection of Hepa-1c1c7 cells pretreated by compounds $\mathbf{1}, \mathbf{2}, \mathbf{4}$ or $\mathbf{5}$, seems to be largely attributed to their NQO1 inducer activities (Fig. 2) that resulted in detoxification of MD compared to MD treated cells.

\section{Conclusion}

The present study shed light on the mechanism-based potential of the phenolic constituents of the ornamental plant $B$. cristata var. alba as chemopreventive agents. As shown, this activity is through the induction of the cytoprotective enzyme NQO1 at the activity and protein expression levels.

\section{Additional file}

Additional file 1: Supplementary data contains ten supplementary figures showing the $\mathrm{H}$ and 13C-NMR data of isolated compounds 1-5. (PDF $1541 \mathrm{~kb}$ )

\section{Acknowledgments}

This work was funded by the Deanship of Scientific Research (DSR), King Abdulaziz University, Jeddah, under grant No. (166-929-D1435). The authors, therefore, acknowledge with thanks DSR technical and financial support.

\section{Funding}

This work was funded by the Deanship of Scientific Research (DSR), King Abdulaziz University, Jeddah, under grant No. (166-929-D1435).

Availability of data and materials

All data generated or analysed during this study are included in this published article [and its Additional file 1].

\section{Authors' contributions}

AME, HMA, HEK performed extraction, isolation and identification of pure compounds and shared in writing the manuscript. ARH carried out the biological study and shared in writing the manuscript. AMA suggested the idea of the manuscript, shared in fund raising and edited the manuscript. All authors read and approved the final manuscript.

\section{Competing interests}

The authors declare that they have no competing interest.

\section{Publisher's Note}

Springer Nature remains neutral with regard to jurisdictional claims in published maps and institutional affiliations.

\section{Author details}

${ }^{1}$ Department of Natural Products, Faculty of Pharmacy, King Abdulaziz University, Jeddah 21589, Saudi Arabia. ${ }^{2}$ Department of Pharmacognosy, Faculty of Pharmacy, Cairo University, Cairo 11562, Egypt. ${ }^{3}$ Phytochemistry Department and Biology Unit lab 610, Central Laboratory for the

Pharmaceutical and Dug Industries Research Division, National Research Centre, Giza, Dokki 12622, Egypt. ${ }^{4}$ Department of Pharmacognosy, Faculty of Pharmacy, Minia University, Minia 61519, Egypt. ${ }^{5}$ Department of Pharmaceutical Sciences, College of Clinical Pharmacy, King Faisal University, Al-Ahsa, Saudi Arabia. ${ }^{6}$ Department of Clinical Pharmacy, Faculty of Pharmacy, King Abdulaziz University, Jeddah 21589, Saudi Arabia.

Received: 25 January 2018 Accepted: 18 April 2018

Published online: 22 May 2018

\section{References}

1. Ali NS, Khalil HZ. Cancer prevention and early detection among Egyptians. Cancer nursing. 1996;19(2):104-11.

2. Surh Y-J. Cancer chemoprevention with dietary phytochemicals. Nat Rev Cancer. 2003:3(10):768-80.

3. Manson MM, Gescher A, Hudson EA, Plummer SM, Squires MS, Prigent SA. Blocking and suppressing mechanisms of chemoprevention by dietary constituents. Toxicol Lett. 2000;112:499-505.

4. Zhao CR, Gao ZH, Qu XJ. Nrf2-ARE signaling pathway and natural products for cancer chemoprevention. Cancer Epidemiol. 2010;34(5):523-33.

5. Hamed AR, Hegazy M-EF, Higgins M, Mohamed TA, Abdel-Azim NS, Pare PW, Dinkova-Kostova AT: Potency of extracts from selected Egyptian plants as inducers of the Nrf2-dependent chemopreventive enzyme NQO1. J Nat Med. 2016;70(3):683-8.

6. Crowell JA. The chemopreventive agent development research program in the division of Cancer prevention of the US National Cancer Institute: an overview. Eur J Cancer. 2005;41(13):1889-910. 
7. Harraz FM, El-Halawany AM, El Gayed SH, Abdel-Sattar E. Iridoid glycosides from Barleria trispinosa. Nat Prod Res. 2009;23(10):903-8.

8. Hemalatha K. Chemical constituents isolated from leaves of Barleria cristata Linn. Int J Pharm Bio Sci. 2012:3(1):609-15.

9. Swanson $\mathrm{H}$ : Mechanisms by which flavonoids exert their beneficial anticancer effects. In: Flavonoids, Inflammation and Cancer. edn. Singapore: World Scientific; 2016; 25-58.

10. Benson AM, Hunkeler MJ, Talalay P. Increase of $\mathrm{NAD}(\mathrm{P}) \mathrm{H}$ :quinone reductase by dietary antioxidants: possible role in protection against carcinogenesis and toxicity. Proc Natl Acad Sci U S A. 1980;77(9):5216-20.

11. Bradford MM. A rapid and sensitive method for the quantitation of microgram quantities of protein utilizing the principle of protein-dye binding. Anal Biochem. 1976;72(1-2):248-54

12. Vichai V, Kirtikara K. Sulforhodamine B colorimetric assay for cytotoxicity screening. Nat Protoc. 2006;1(3):1112-6.

13. Dietz BM, Kang Y-H, Liu G, Eggler AL, Yao P, Chadwick LR, Pauli GF, Farnsworth NR, Mesecar AD, Van Breemen RB. Xanthohumol isolated from Humulus lupulus inhibits menadione-induced DNA damage through induction of quinone reductase. Chem Res Toxicol. 2005;18(8):1296-305.

14. Abdallah HM, Mohamed MA, Abdou AM, Hamed MM, Abdel-Naim AB, Ashour OM. Protective effect of Centaurea pallescens Del. Against $\mathrm{CCl}_{4}^{-}$ induced injury on a human hepatoma cell line (Huh7). Med Chem Res. 2013;22(12):5700-6.

15. Shabana MM, El-Sherei MM, Moussa MY, Sleem AA, Abdallah HM. Investigation of phenolic constituents of Carduncellus eriocephalus Boiss. Var. albiflora Gauba and their biological activities. Nat Prod Commun. 2007;2(8):823-8.

16. Wu TY, Saw CL, Khor TO, Pung D, Boyanapalli SS, Kong AN. In vivo pharmacodynamics of indole-3-carbinol in the inhibition of prostate cancer in transgenic adenocarcinoma of mouse prostate (TRAMP) mice: involvement of $\mathrm{Nrf2}$ and cell cycle/apoptosis signaling pathways. Mol Carcinog. 2012;51(10):761-70.

17. Liu W, Tan X, Shu L, Sun H, Song J, Jin P, Yu S, Sun M, Jia X. Ursolic acid inhibits cigarette smoke extract-induced human bronchial epithelial cell injury and prevents development of lung cancer. Molecules. 2012;17(8): 9104-15.

18. Zhang Y, Talalay P, Cho CG, Posner GH. A major inducer of anticarcinogenic protective enzymes from broccoli: isolation and elucidation of structure. Proc Natl Acad Sci U S A. 1992;89(6):2399-403.

19. Radjendirane V, Joseph P, Lee YH, Kimura S, Klein-Szanto AJ, Gonzalez FJ, Jaiswal AK. Disruption of the DT diaphorase (NQO1) gene in mice leads to increased menadione toxicity. J Biol Chem. 1998;273(13):7382-9.

20. Chang LC, Gerhauser C, Song L, Farnsworth NR, Pezzuto JM, Kinghorn AD. Activity-guided isolation of constituents of Tephrosia purpurea with the potential to induce the phase II enzyme, quinone reductase. J Nat Prod. 1997;60(9):869-73.

21. Tanaka T, Kawabata K, Kakumoto M, Makita H, Ushida J, Honjo S, Hara A, Tsuda $\mathrm{H}$, Mori H. Modifying effects of a flavonoid morin on azoxymethane-induced large bowel tumorigenesis in rats. Carcinogenesis. 1999;20(8):1477-84.

22. Kawabata K, Tanaka T, Honjo S, Kakumoto M, Hara A, Makita H, Tatematsu N, Ushida J, Tsuda H, Mori H. Chemopreventive effect of dietary flavonoid morin on chemically induced rat tongue carcinogenesis. Int J Cancer. 1999; 83(3):381-6

23. Burdette JE, Chen SN, Lu ZZ, Xu H, White BE, Fabricant DS, Liu J, Fong HH, Farnsworth NR, Constantinou Al. black cohosh (Cimicifuga racemosa L.) protects against menadione-induced DNA damage through scavenging of reactive oxygen species: bioassay-directed isolation and characterization of active principles. J Agric Food Chem. 2002;50(24):7022-8.

24. Dinkova-Kostova AT, Fahey JW, Talalay P. Chemical structures of inducers of nicotinamide quinone oxidoreductase 1 (NQO1). Methods Enzymol. 2004; 382:423-48

\section{Ready to submit your research? Choose BMC and benefit from:}

- fast, convenient online submission

- thorough peer review by experienced researchers in your field

- rapid publication on acceptance

- support for research data, including large and complex data types

- gold Open Access which fosters wider collaboration and increased citations

- maximum visibility for your research: over $100 \mathrm{M}$ website views per year

At BMC, research is always in progress.

Learn more biomedcentral.com/submissions 